\title{
Agroecosystem Degradation Evaluation of Broccoli (Brassica oleracea) Farm Using Some Biotic Indices in Batu, East Java, Indonesia
}

\author{
Lina Mariantika ${ }^{1}$, Catur Retnaningdyah², Endang Arisoesilaningsih ${ }^{2}$ \\ ${ }^{1}$ Master Program of Biology, Faculty of Mathematics and Natural Sciences, University of Brawijaya \\ ${ }^{2}$ Biology Department, Faculty of Mathematics and Natural Sciences, University of Brawijaya, \\ Jl. Veteran, Malang, East Java, Indonesia
}

\begin{abstract}
The aim of this study was to evaluate the degradation of broccoli agroecosystem in Batu caused by a longterm of intensive farming and of synthetic chemical exposure using some biotic indices. Evaluation covered on quality of habitat, biodiversity, and environmental services in three organic and intensive farm, each Batu, Bumiaji, and Junrejo Regencies, using five repetitions in each location. Habitat quality was evaluated by measuring the soil organic matter, water irrigation and soil suspension $\mathrm{pH}$, electric conductivity, and water turbidity in situ. Biodiversity quality was evaluated by determining the score of Importance Value Index (IVI), Shannon-Wiener Diversity Index ( $\left.\mathrm{H}^{\prime}\right)$ and Margalef's Richness Index (R) soil fauna using handsorting within the area of $\mathrm{I}^{2}$, as well as refugial vegetation. Environmental service quality was evaluated by scoring using the Ecosystem Integrated Assessment (EIA). The data were analyzed statistically using Principal Component Analysis (PCA). The result showed that soil organic matter and $\mathrm{pH}$ were obviously higher, while the irrigation water was less turbid in organic farming rather than the intensive one. Furthermore, the $\mathrm{H}^{\prime}$ and $\mathrm{R}$ indices proved that biodiversity quality in organic farming field was higher ( $H^{\prime}$ score 1.4-1.9 and R 3.5-4.0) comparing to those of intensive farming ( $H^{\prime}$ score $0.6-0.9$ and $R$ 1.2-1.6). Whereas, the ecosystem service based on EIA index revealed that the organic agroecosystem showed a fair to good quality with the score 3.0-4.3. It was higher than those of intensive farming which was classified as poor to fair with the score 1.7-2.8. Therefore, the organic broccoli agroecosystem in Batu provided a better habitat for biodiversity conservation and greater the environmental service as a sustainable farming system.
\end{abstract}

Key words: Agroecosystem, Biodiversity, Ecological services, Intensive, Organic

\section{INTRODUCTION}

In order to increase the agricultural productivity, farmers in Indonesia generally practiced agricultural intensification which often leads to a decrease in the environmental quality and health [3]. This is due to physical and chemical damage to the environment and the decline of biodiversity. Intensive cultivation, fertilization, pest eradication and monoculture cultivation in conventional farming systems resulted in a significant decrease in soil fauna and soil quality, thus ecosystem become unstable [6]. To avoid the unsustainability and negative impacts of ecosystem intensification management, organic farming becomes one of the solutions of sustainable agriculture systems.

The main objective of organic agriculture was to provide food that is safe for the health of producers and consumers, not to damage the environment and based on sustainable principles [10]. Organic farming management provides many benefits by improving the quality of land biodiversities such as animal, productivity, and soil carbon uptake so that the health of the land maintained [25]. However, the application of organic agriculture has many difficulity, such as pesticide residue contamination at irrigation water, lower productivity, and susceptible to attack of plant disturbing organism [23].

Meanwhile, Batu City has made organic farming system as one of the vision of government in 2012-2017 [17]. Organic farming systems are promoted in every sub-district in Batu, but farmers haven't fully implemented yet because of their limitations. Most organic farming lands are still adjacent to conventional farmlands that still use synthetic chemicals and pesticides massively. But residual contamination flow on same irrigation water of organic farmland. Contamination of chemical fertilizer residues and synthetic pesticides on organic farming causes the health of agroecosystems vary and adversely affect the agricultural environment [22]. This case is on broccoli farming, which is one of high demand vegetables and reaches $35 \%$ of all agricultural land in Batu [4].

Correspondence address:

Lina Mariantika

Email : lina.mariantika@gmail.com

Alamat : Master Program of Biology, Mathmatics and Sains Faculty, Brawijaya University, Malang 
Study about broccoli farming especially related to evaluation of quality of agro ecosystem and ecological services using biotic index has not been discovered yet. Based on this situation, the quality of broccoli agroecosystem is important to be discover. This study aims to evaluate the broccoli farming ecosystem in Batu City due to exposure of synthetic chemical residues and compare it with organic farming ecosystems. These evaluations were performed using the assessment of several biotic indexes such as Importance Value Index (IVI), Shannon-Wiener diversity index $\left(\mathrm{H}^{\prime}\right)$, Margalef taxa richness diversity index (R), and Ecosystem Integrated Assessment (EIA) index [13].

\section{MATERIAL AND METHODS Study Site}

This research was conducted on organic and intensive broccoli (Brassica oleracea) farming in three sub-districts in Batu, East Java, namely Batu District which is located at $7^{\circ} 51^{\prime} 19$ "S and $112^{\circ} 30^{\prime} 36^{\prime \prime} \mathrm{E}$ on $1215 \mathrm{~m}$ above sea level, District of Bumiaji located at $7^{\circ} 49^{\prime} 21$ "S and $112^{\circ} 31^{\prime} 29^{\prime \prime} \mathrm{E}$ on $1305 \mathrm{~m}$ above sea level, and Junrejo District located at $7^{\circ} 53^{\prime} 00$ "S and $112^{\circ} 33^{\prime} 50^{\prime \prime} \mathrm{E}$ on $875 \mathrm{~m}$ above sea level (figure 1). This area clasified on wet climate with an average rainfall of $3230 \mathrm{~mm}$ and $93 \%$ humidity in 2017 [2]. In each sub-district observations were conducted on five organic and intensive farms, and three duplication were performed for each site.

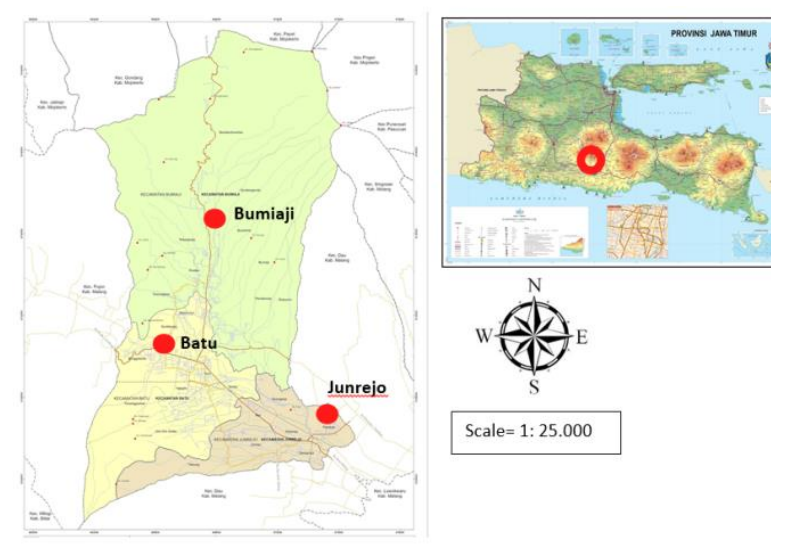

Figure 1. Study site in three regencies at Batu, which are Batu, Bumiaji, dan Junrejo

\section{Evaluation of Agroecosystem Components}

Agro-ecosystem components which was evaluated in this research includes habitat, biodiversity and environmental service. Habitat of broccoli farming were evaluated by measuring in situ soil organic matter, $\mathrm{pH}$ and water conductivity and soil suspension, and turbidity of irrigation water. The biodiversity of broccoli farming were evaluated by determining the profile of IVI, $\mathrm{H}^{\prime}$ and $\mathrm{R}$ for refugia vegetation and soil fauna. Refugia vegetation analyzes using $1 \mathrm{~m}^{2}$ sampling method and also observed the density, frequency and taxa of refugia plant. The soil fauna profile was observed by hand sorting method in $1 \mathrm{~m}^{2}$ quadrant [15]. Environmental services were evaluated with the EIA index to assess agroecosystem management including vegetation, soil, hydrology, and interaction with the surrounding landscape. The Ecological Integrity Assessments performed by outline a general conceptual model that identifies the major ecological attributes, provided a narrative description of declining integrity levels based on changes to those ecological attributes, and provided a scorecard matrix by which the metrics are rated and integrated into an overall index of ecological integrity [13].

\section{Data Analysis}

The data were analyzed descriptively to describe agroecosystem profile of organic and intensive broccoli vegetables in each research location. Statistical analysis of different ANOVA test was conducted to determine the difference of each variable at organic and intensive farming. Biplot Principal Componsibility Analysis (PCA) statistical analysis was performed to determine the interaction between variables and characters that characterize each location. Statistical analysis was performed using PAST 3.15 software.

\section{RESULT AND DISCUSSION}

\section{Advantages of Organic Broccoli Habitat Quality}

Based on Figure 2 known that the soil organic matter, soil $\mathrm{pH}$ and $\mathrm{pH}$ of water in organic broccoli farming were significantly higher than in intensive farming. The soil organic matter at organic farming was higher than in intensive farming (Figure 2a). This condition showed that soil and water conditions in organic farms were better due to higher soil nutrient availability. The availability of soil nutrient enhanced the microorganism nutrients, increased the aggregation level and the aeration, soil structure more stable and higher soil's ability to stored water and higher resilience [5]. In addition, the value of soil organic matter over $5 \%$ was one of the good organic farming representation $[10,16]$.

The $\mathrm{pH}$ of water and soil was higher in organic farming (Fig. 2b, 2c) and closed to neutral 
than in intensive farming, thus supported the absorption rate and solubility of nutrients, ions, and nutrients [19]. The neutral $\mathrm{pH}$ also gave an advantages the availability of Sodium ( $\mathrm{Na}$ ) and Molybdenum (Mo) to promoted plant growth and development [1]. In contrast, the $\mathrm{pH}$ in intensive farming was lower than in organic soil due to the addition of synthetic fertilizer by farmers, which contains urea $\left(\left(\mathrm{NH}_{2}\right)_{2} \mathrm{CO}\right)$ and high ammonium sulfate ((NH4) 2SO4). This condition can decreased solubility of macro nutrients at soil such as Calcium (Ca), and Magnesium (Mg), which can inhibited plant growth, increased the risk of Aluminium toxicity (Al) and phosphorus (P) bind instead of soil nutrient [1].

Soil conductivity, water conductivity and water turbidity in intensive farming were significantly higher than in organic farming (fig $2 d$, $2 e, 2 f)$. This was due to the presence of synthetic fertilizer or pesticide residue applied in intensive soil, and low soil organic matter. This situation caused the rate of soil infiltration reduced, thus reduced soil and plant fertility [7]. Water turbidity of irrigation water in intensive farming was significantly higher than in organic farming (Figure 2f). This is due to soil erosion and leaching caused by low soil organic matter and soil porosity [16]. It also showed that water turbidity levels in intensive farming were higher, which is influenced by the higher content of ions due to exposure to synthetic chemicals from fertilizers and pesticides, which can threated plant health and sustainability [21].

\section{Complexity of Biodiversity at Organic Broccoli Farming}

The species diversity of refugia and fauna found in organic farming was higher than in intensive farming. This was proved by the higher diversity index $\left(\mathrm{H}^{\prime}\right)$ and taxa richness index $(\mathrm{R})$ in organic farming rather than intensive farming, although it was still in the medium range, between 1.4-1.9 for $\mathrm{H}^{\prime}$ value (figure 3a), and 3.5 4.3 for $R$ value (figure $3 b$ ). According to the large diversity index of Shannon-Wiener and Margalev's diversity index, the diversity of refugia and fauna was in the medium range, and no species dominate in the ecosystem, so competition and food chain were stable [15]. In contrast, on intensive farms found low diversity and diversity index values, mean low diversity, presence of dominance of a particular species, and low species evenness. This could be due to the monoculture planting and weeding [20].

The refugia vegetation (buffer plant) at the organic farming was intentionally planted by farmers to become a fauna microhabitat for polinator, herbivor, predator and pest. The presence of refugia plants was also very beneficial because it improves the biological control system, so farmers did not require to use synthetic pesticides [8]. Refugia plants were intentionally planted in organic farms, in addition to applied the polyculture system, as well as an efforts to minimized pests and plant diseases [12]. Types of refugia crops on organic farming were vary such as Capsicum, Cymbopogon, Solanum, Brassica, and Raphanus groups (Figure 4a) in order to attract the natural enemies of the Brassicaceae family pest. In contrast to buffer plants found in intensive farming, most of it was the weeds of Cyperaceae and Graminiae members of Monocotyledoneae. Both had a more limited ecological role as producers and habitats for soil fauna [11].

The soil fauna community structure shown by IVI data (Figure 4b) showed that soil fauna found in organic farming were various kinds, from pests, predators, herbivores and pollinators, and no dominance of a particular species. This proved that in organic farming the diversity of species was higher so that the food chain was more complex and the ecosystem was more stable [14]. In contrast to fauna diversity in intensive farming largely dominated by the families of Formicidae and Arachnidae (figure 4b). This suggested that the diversity of soil fauna in intensive farmland was poorly maintained, and was dominated by a certain species that had ecological functions as predators. The abundance of Formicidae and Arachnidae in an ecosystem showed that ecosystems and food chains were less stable because of higher predators [18]. This situation indicated that intensive agricultural land was less supportive of soil fauna life and may threaten the sustainability of farmland.

\section{Degradation of Intensive Brocoli Farming}

According to Ecosystem Integrated assessment known that organic broccoli farming had good ecosystem quality that was in the range of 3.1-4.1 (figure 5). This illustrated that the ecosystem was able to control the disturbance that occured so ecosystem integrity was more stable. 


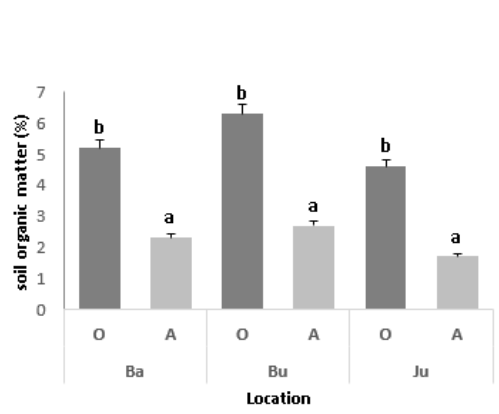

(a)

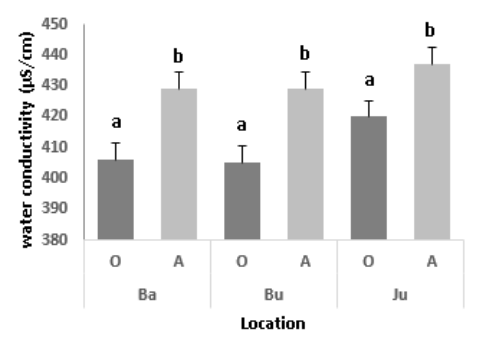

(d)

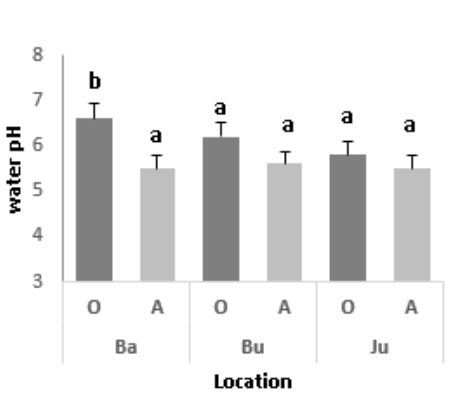

(b)

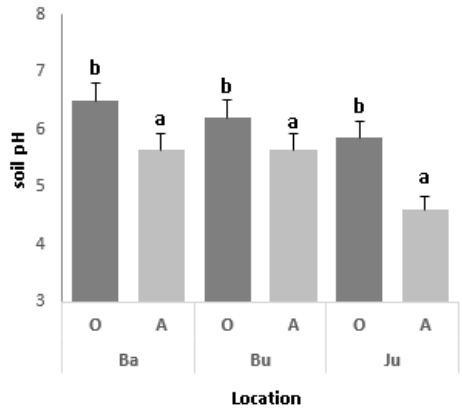

(c)

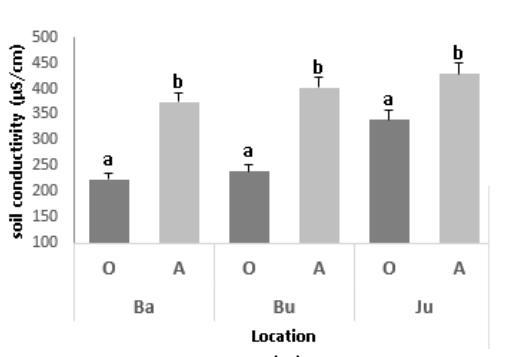

(e)

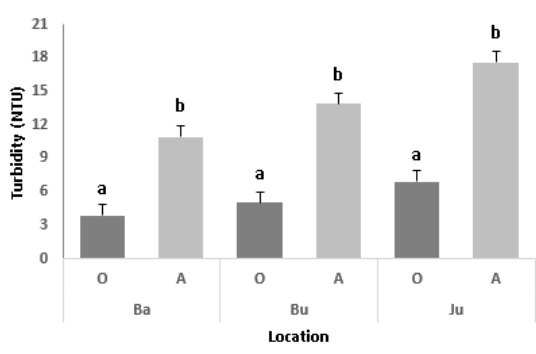

(f)

Figure 2. Average of soil organic matter (a), water $\mathrm{pH}(\mathrm{b}), \mathrm{pH}$ of soil suspension (c), water conductivity (d), soil conductivity (e), and water turbidity (f) at organic and intensive farming in three district at Batu. A-b notation show the real difference of quality between physicochemical charachteristic in both organic and intensive farming.

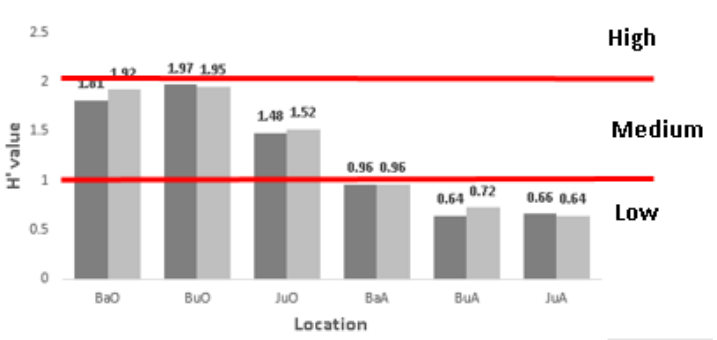

(a)

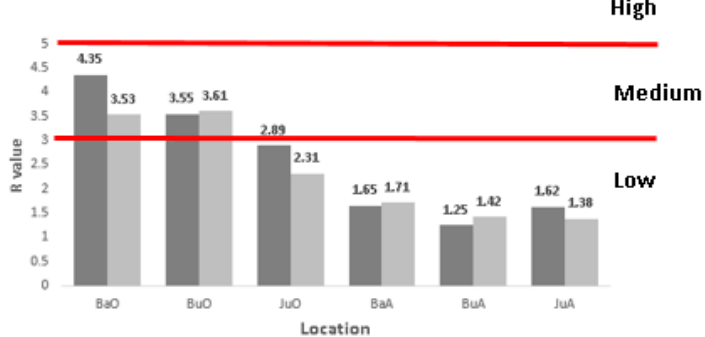

(b)

Figure 3. Shannon-Wiener Diversity index value $\left(H^{\prime}\right)$ (a) and Margalef's richness index value $(R)(b)$ of refugia vegetation and fauna. Location: BuO: Bumiaji Organic; BaO: Batu Organic; JuO: Junrejo Organic; BuA: Bumiaji Intensive; BaA: Batu Intensive; JuA: Junrejo intensive

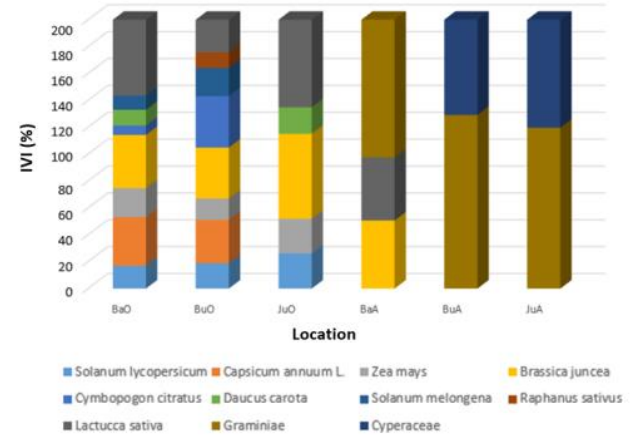

(a)

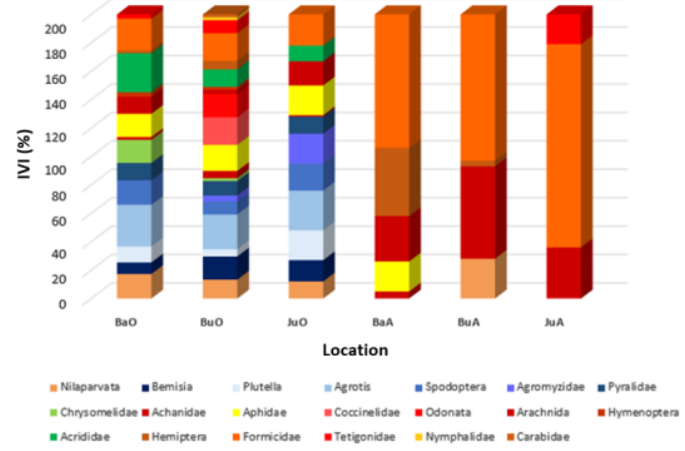

(b)

Figure 4. Community structure of refugia vegetation (a) and fauna (b) by Important Value Index (IVI).

Location: BuO: Bumiaji Organic; BaO: Batu Organic; JuO: Junrejo Organic; BuA: Bumiaji Intensive; BaA: Batu Intensive; JuA: Junrejo intensive 


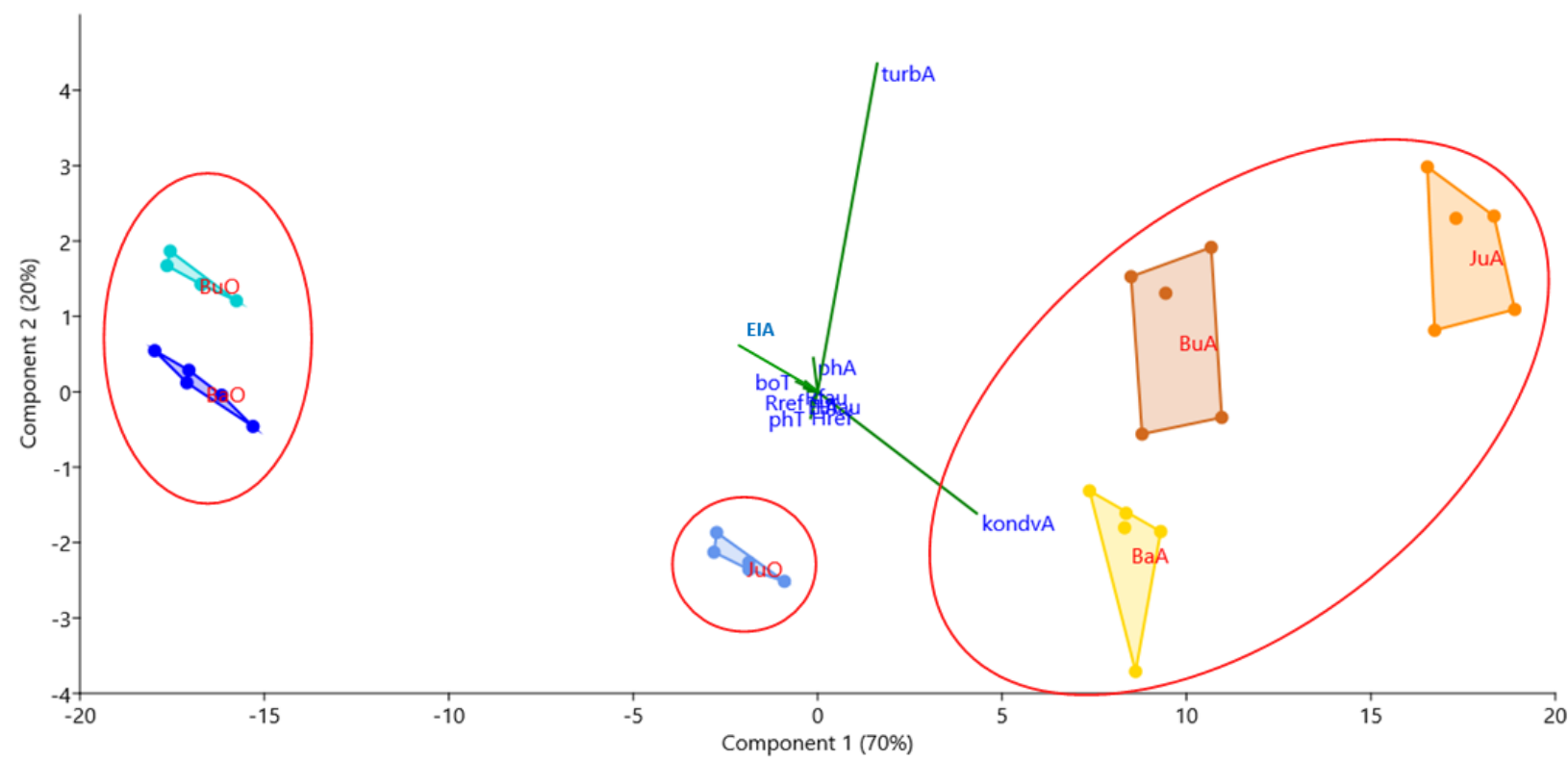

Figure 6. Grouping of broccoli agroecosystem based on biplot analysis.

Note: BuO: Bumiaji Organic; BaO: Batu Organic; JuO: Junrejo Organic; BuA: Bumiaji intensive; BaA: Batu intensive; JuA: Junrejo intensive; turbA: water turbidity; kondvA: water conductivity; EIA: EIA index score; boT: soil orgainic meter; water phA; phT: $\mathrm{pH}$ tanah; Rref: nilai indeks R vegetasi refugia; Rfau: nilai indeks R fauna; Href: nilai indeks $\mathrm{H}^{\prime}$ vegetasi refugia; $\mathrm{Hfau}$ : nilai indeks $\mathrm{H}^{\prime}$ fauna tanah

In goor-categorized ecosystems, all ecological attributes such as vegetation, soil and hydrological composition and structure were well functioned, and many species of indicators played an important role in the food chain [13]. In some cases, good ecosystems can also found invasive and exotic species, but in small quantities and had little effect on the ecosystem. In addition, this ecosystem were found many animals and plants that act as a key species [9].

In contrast to intensive farming, which was classified as having poor quality according to the EIA index that was in the range of values 1.92.5 (figure 5). This situation indicated that in this ecosystem changes land characteristics, and only a small that was still natural. In this ecosystem there had been many disruptions, such as pest attacks exceeding the economic threshold, simplifying the food chain, intensification of land management, and contamination of synthetic chemicals, so that ecosystem components were less able to cope with the disorder.

In poor-categorized ecosystems quality, vegetation structure and composition, soil conditions, and hydrology were unnatural, and did not support the life of key indicator and species species to maintain ecological balance [13]. In this condition, the presence of invasive and exotic species had a negative effect, and the plant and animal indicators can not stabilized the disturbance [24]. This suggested that intensive broccoli farming ecosystems were degraded and threatened to become unsustainable agroecosystems. This situation required further conservation efforts such as diversity restoration, habitat manipulation, and land conversion to organic farming systems.

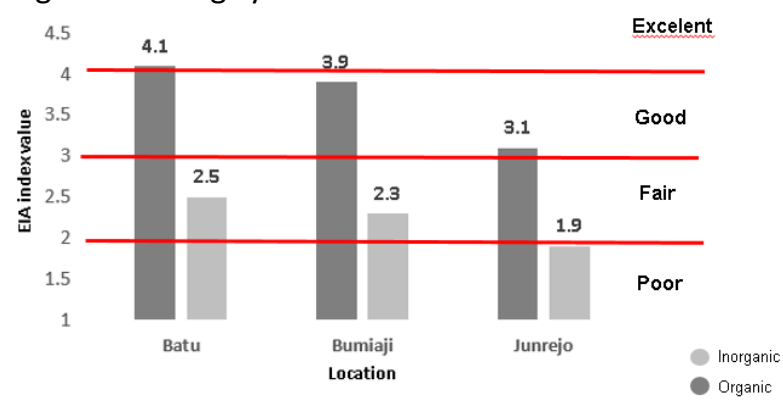

Figure 5. EIA index value at each location

\section{Advantages of Organic Broccoli Agroecosystem}

Based on integrative analysis of all agroecosystem variables in the organic and intensive farming of Batu City, six location showed uniqueness according to location and the real difference of organic broccoli farming. In organic gardens were characterized by high EIA index values, organic matter percentage, biodiversity index $\left(H^{\prime}\right)$ and species richness index $(R)$, also soil $\mathrm{pH}$ and water $\mathrm{pH}$ values (Figure 6). Organic broccoli farming in Batu and Bumiaji sub-districts formed a separate group with organic broccoli 
gardens in Junrejo Sub-district. This was because the management of organic broccoli farming in Junrejo District was less intensive, and its location was still adjacent to the conventional intensive farming.

Intensive farming in the three subdistricts of Batu City were characterized by great turbidity and conductivity values. This happened because of the residue of synthetic fertilizers or pesticides applied in the intensive farming, and the low soil organic matter. Based on the biplot analysis, the three intensive broccoli farming in Kota Batu formed a group which means that conditions in these three locations had almost the same characteristics.

Figure 6 also explained that the value of turbidity of water and conductivity in six locations of broccoli gardens in Batu City had a high variation. Figure 6 also showed that conductivity negatively affects the value of the EIA index, which means the magnitude of conductivity can decreased the value of environmental services. The higher conductivity signified the higher ions that can threated soil fertility and the rate of soil infiltration [7]. This can happened in intensive farming because intensive fertilizers and synthetic pesticides are used to increase productivity.

\section{CONCLUSION}

The organic broccoli (Brassica oleracea) farming system in Batu City provided better environmental services and can improved the quality of agricultural land and biodiversity. The quality of agricultural services ecosystem services can increased in line with the better and higher diversity of soil fauna and refugia vegetation, the percentage of soil organic matter, soil $\mathrm{pH}$ and water $\mathrm{pH}$. Synthetic chemicals applied in the vegetable garden can threated the sustainability of agriculture, because it can increased soil conductivity, water conductivity, and water turbidity. Periodic review and detailed strategic planning needs to be done by farmers, farmer groups, and Batu City government to evaluate and continue the organic farming system that has been done as a good, healthy, and sustainable agricultural system.

\section{ACKNOWLEDGEMENTS}

Our sincere gratitude to the farmers' groups in Batu, Bumiaji and Junrejo Sub-districts of Batu City, District officials and Agriculture Service of Batu City. We are also thanks to all members of the Research Group of Biotechnology for Conserving the Sustainably Tropical
Ecosystem, and Mr. Purnomo as Laboratory of Ecology Laboratory and Animal Diversity of Biology Department Faculty of Mathematics and Natural Sciences Brawijaya University.

\section{REFERENCES}

[1] Aluko, O.A., Olanipekun, T.O., Olasoji, J.O., Abiola, I.O., Adeniyan, O.N., Omena, E.C., Kareem K.O., and Douglas A.I. 2014. Effect Of Organic and Intensive Fertilizer on the Yield and Nutrient Composition. Global Journal of Agriculture Research. Vol 2 No 3:1-9.

[2] Badan Meteorologi dan Geofisika Kabupaten Malang. 2017. Data Iklim Tahunan 2017. BMKG Karangploso Malang.

[3] Badan Penelitian dan Pengembangan Pertanian. 2011. Statistik Badan Penelitian dan Pengembangan Pertanian. Kementrian Pertanian Republik Indonesia. Jakarta.

[4] Badan Pusat Statistik Kota Batu. 2015. Statistik Daerah Kota Batu. Badan Pusat Statistik Kota Batu.

[5] Brock, C., H.R. Oberholzer, and U. Franko. 2017. Soil Organic Matter Balance as a Practical Tool for Environmental Impact Assessment and Management Support in Arable Farming. European Journal of Soil Science. Vol 68: 951-952.

[6] Departemen Pertanian. 2003. Penerapan Pengendalian Hama Terpadu (PHT) dalam Mendukung Ekspor Produk Hortikultura. Dirjen Bina Produksi Hortikultura. Kementrian Pertanian Republik Indonesia. Jakarta.

[7] Funk, Roger C. 2012. Comparing Organic and Anorganic Fertilizers. Review Article of the Davey Tree Expert Company. UK.

[8] Harvey C.A., C. Villaneuva, J. Vilacis, M.Chacon, M. Munoz, M. Lopes, M. Ibrahim, R. Gomez, R. Taylor, J.Martinez, A.Navaz, J. Saens, D. Sanchez, A. Medina, S. Vilchez, B. Hernandez, A. Peresz, F. Ruis, F. Lopez, I. Lang, and F.L. Sinclair. 2005. Contribution of Live Fences to Ecological Integrity of Agricultural Lanscape. Journal of Agriculture, Ecosystem and Environment Vol. 111: 200230.

[9] Hess, George R., Daniel A. Fiscus, Anne S Hellkamp, Betty F. McQuaid, Michael J. Munster, Steven L. Peck, Lee Campbell, and Steven R. Shafer. 2010. A Conceptual Model and Indicators for Assessing the Ecological Condition of Agricultural Lands. Journal of Environmental Quality. ProQuest pg. 728. 
[10] Jaringan Kerja Pertanian Organik Indonesia. 2005. Standar Pertanian Organik Indonesia. General Assembly Jakerpo. Yogyakarta.

[11] Kimmins, J.P, 1987. Forest Ecology. Macmillan Publishing Co. New York.

[12] Lampkin, N.H, Pearce, B.D.,Leake A.R., Creissen H., Gerrard C.L., Girling R., Lloyd, S., Padel S., Smith J., Smith, L.G., Vieweger A., and Wolfe M.S. 2015. The Role of Agroecology in Sustaiable Intensification. Report for the Land Use Policy Group. Organic Research Centre, Elm Farm and Game \& Wildlife Conservation Trust.

[13] Langendoen, F. D., J. Rocchio, S. Thomas, M. Kost, C. Hedge, B. Nichols, K. Walz, G. Kittel, S. Menard, J. Drake, and E. Muldavin. 2012. Assessment of wetland ecosystem condition across landscape regions: A multi-metric approach. Part B. Ecological Integrity Assessment protocols for rapid field methods (L2). Environmental Protection Agency Office of Research and Development, Washington, DC.

[14] Lori M., Symnaczik S., Mader, P. De Deyn, and G. Gattinger. 2017. Organic Farming Enhances Soil Microbial Abundance and Activity. PLoS One 12 (7):e0180442.

[15] Magguran, Anne E. 2013. Ecological Diversity and Its Measurement. Springer Science Bussiness Media. UK.

[16] Mapfumo, P., Mtambanengwe, F., and Vanlauwe, B. 2007. Organic Matter Quality and Management Effects on Enrichment of Soil Organic Matter Fractions inContrasting Soils in Zimbabwe. Plant Soil 296 (1): 137-50.

[17] Pemerintah Kota Batu. 2012. Visi Misi Kota Batu. http://website.batukota.go.id/ diakses 1 Februari 2017.

[18] Pranadji, T.S., and W.K. Sejati. 2008: Pengelolaan Serangga dan Pertanian Organik Berkelanjutan di Pedesaan. Jurnal Forum Penelitian Agronomi. Vol 23 (11): 38-47.

[19] Raissi, Abdolshakoor, Mohammad Galavi, Mahmood Ramroudi, Sayed Roholla Mousavi, and Mohammad Navaz Rasoulizadeh. 2012. Effect of Phospate biofertilizer, organic manure and chemical fertilizer on yield, yield components and seed capabilities of isabgol (Plantago ovate). International Journal of Agriculture and Crop Sciences Vol. 4 (24) 1821-1826.
[20] Schneiders, A., Van Daele, T., Van Landuyt, W., and Van Reeth, W., 2012. Biodiversity and ecosystem services: complementary approaches for ecosystem management? Jurnal of Ecology Indicator. Vol 21: 123-133.

[21] Savci, Serpil. 2012. An Agricultural Pollutant: Chemical Fertilizer. International Journal of Environmental Science and Development Vol 3 No. 1.

[22] Suparni, Nugroho, S.P., and Suputa. 2017. Population of Herbivorous and Carnivorous Arthropods in Rice Field Ecosystem odifief with Vermicompost and Flower Plants. Journal of Agricultural Sciences Vol 2. No 2: 048-055.

[23] Sutanto, R., 2002. Pertanian Organik. Kanisius. Yogyakarta.

[24] Witrianto, Roma., M. Hadi, and Rully R. 2015. Keanekaragaman Makroarthropoda Tanah di Lahan Persawahan Organik dan Anorganik Desa Bakalrejo Kecamatan Susukan Kabupaten Semarang. BIOMA Vol 17 No. 1 Hal 21-26.

[25] Yadav, S.K., Subhash Babu, Kalyan Singh, and Suresh Pal. 2013. A Review Organic Farming for Sustainable Agriculture in Nothern India. International Journal of Agronomy Article ID 718145 . 